\title{
A Special Introduction: A New Journal for the Challenge of Environment-Behaviour Research
}

\author{
Christopher Peter Spencer \\ The University of Sheffield, Sheffield, England, \\ United Kingdom \\ C.P.Spencer@sheffield.ac.uk
}

A new Asian Environment-Behaviour (EB) journal for a new decade is greatly to be welcomed: it places centre-stage EB research that largely emanates from a region which is newly contributing to a world literature that had previously over-represented American and European research settings. This is exciting for the whole world community of EB scholars and practitioners, which includes architects and the design professionals; psychologists and the social scientists; and geographers and the environmental sciences.

eISSN 2514-751X (C) 2016 The Authors. Published for AMER ABRA by e-International Publishing House, Ltd., UK.. This is an open access article under the CC BY-NC-ND license (http://creativecommons.org/licenses/by-ncnd/4.0/). Peer-review under responsibility of AMER (Association of Malaysian Environment-Behaviour Researchers), ABRA (Association of Behavioural Researchers on Asians) and cE-Bs (Centre for EnvironmentBehaviour Studies), Faculty of Architecture, Planning \& Surveying, UniversitiTeknologi MARA, Malaysia.

http://dx.doi.org/10.21834/aje-bs.v1i1.162 
The importance of Environment-Behaviour research is now widely recognized, and hence the timeliness of ajE-Bs. The field is now making substantial applied contributions to a whole range of areas, as well as reshaping basic theories in many of the home disciplines: even economics is now acknowledging the need to take a more psychologically-realistic account of behaviour-in-its-setting!

Read any newspaper, and potential applications of EB research leap out: for example, public attitudes to climate change, renewable energy and sustainability; and other resource issues, equity, sharing the commons. (There are colleagues who publish such research under the banner of Conservation Psychology, as well as EB)

Another group of concerns: everywhere in the papers, there are discussions which are essentially about the relationship between design and well-being: for example, could the causes of crime and incivilities be attributed to local conditions? How far is public health (both physical and mental) attributable to environmental factors such as poorly designed housing projects? How could these be ameliorated? EB research has much to offer on all of these topics.

Again, can one build a sense of community through design? How can one involve residents in the redesign and running of their neighbourhoods? If criminologists have been able to demonstrate that potential incoming crime is deflected from a housing project because outsiders perceive it to be a 'defensible space', then how can EB specialists assist?

Many stories in the papers will be to do with the loss of natural, 'green' habitat: but can EB studies provide evidence of its importance for people's well-being, evidence sufficiently weighty to convince planners and politicians to factor them in, and spend scarce resources? The empirical case is strong, and is getting ever more precisely specified: we do not have to rely on gut feelings of the pleasantness of the natural environment, nor on unprovable statements about how the ancestors of our species must have lived and looked for resources. Instead, we can use evidence from cognitive psychology and attention restoration theory to show how, for the stress levels and relaxation of current-day human beings, 'green' restorative environments engage fascination or low-effort attention, promoting recovery, of adaptive resources and providing the opportunity to rest and reflect; and that this is why even a natural scene just viewed from a window, let alone a walk in the country, can have measurable benefits (Kaplan, 1995). Using such evidence, we can join the argument that spending money on good design demonstrably saves on the eventual budgets for policing, mental and physical health, as well as humanizing our living spaces (Korpela, Kytta and Hartig, 2002).

Yet another application: have you ever been lost in the country, or in an unfamiliar town, or in a complex building? EB has human wayfinding as one of its research areas; and this research has implications for map-making (how symbols on a page can most easily translate into cognitive maps); signage within buildings and neighbourhoods, and electronic devices for storing and providing local geographic information (with a healthily researched subarea devoted to the needs and strategies of the blind navigator); and strategies for police, and for search and rescue parties based on the likely behaviour of the lost person (we can show that three year olds 
react to the experience of being lost very differently from thirteen year olds and adults) (Cornell and Hill, 2006).

What are the environmental needs of the sections of society, from the toddler to the elderly? EB studies can argue, for instance, that the provision of neighbourhood play facilities for the young are essential for their physical health, and that furthermore, it is through free exploration of that neighbourhood that older children develop a sense of community, belonging and confident personal identity, for the good of all.

Turning to the workplace, EB studies can show how satisfaction and fulfillment from one's work relate to the very physical conditions of that work. Ergonomists have long been able to offer their advice on the micro-design of workplaces: we as EB specialists can add evidence that more symbolic features of the factory or office have a profound effect on people's feelings of self-worth and recognition. Quality of work, commitment, level of absenteeism, turnover, all these economically important factors may be affected by the provision or absence of resources which signal whether one's employer values one.

Other everyday spaces can benefit from existing EB studies: from shopping projects to hospital wards, from entertainment venues to public parks, from meeting rooms to student villages. And indeed, for each of these, there is an extensive literature, offering designers and space managers much immediately applicable evidence. But....and this is a very real challenge to EB ....how far are architects, designers, planners, politicians and media opinion formers aware of the existence of all this evidence? (See for example, Lawson, 2002, Lawson and Spencer,1978)

More fundamentally still, how far do these groups think in terms of an evidence-base for their decision-making? Does the young architect, for instance, start a new design by researching the relevant EB literature ? Certainly, in the architect's office, all the technical literature (on new materials and products; on planning regulations; on local authority requirements for parking provision, etc.) will be to hand; but has the architect's training through university stressed the availability and applicability of the EB literature?

Similarly, does it come naturally for the newspaper columnist to search out the research evidence before writing an opinion piece advising local politicians how the township should be developed, or crime reduced, or our older citizens housed?

But before we castigate the professionals for ignoring our literature, consider our own responsibility as the producers of this evidence base: how easily accessible are we making our findings to such non-specialist audiences? Much academic writing is nigh-on impenetrable, given its elaborated theories which sound to the outsider like pretentious jargon; its findings with the careful data tables and statistics that our academic colleagues judge us by, but which may well cause the potential user to flee.

We must consider how, alongside our academic reports of research we conduct we can find ways of making our findings accessible: of 'giving EB research away'. Here is a challenge for contributors to the journal to consider.

And, returning from the applications of our research to its contribution to the body of basic EB theory, another challenge is to see how regionally-based studies can develop, challenge and 
elaborate the literature already published in other journals and books; and how far thinking and philosophies characteristic of the region can suggest important research questions not so far asked by EB researchers in other regions: Asia is home to such a wide range of approaches.

We need an EB literature which is culturally aware. Some steps towards this have been made in, for instance, studies on children's environments (see the recent review by Evans (2006) and studies by Blaut and colleagues: eg Blades et al, 1998 and Blaut et al, 2003). An excellent example: Louise Chawla has recently co-ordinated world-wide UNESCO-sponsored studies of how children use their local places, how they would redesign them, and how far local authorities would invite them to participate in planning (Chawla, 2002; see also Lynch, 1977, the precursor study of many of Chawla's study sites, a whole generation earlier).

These studies quickly dispel any simple presumption that children's lives are more fulfilled, freer and more engaged with the adult world in the most economically developed world (see Clark and Uzzell's (2006) study of relatively un-fulfilled Western adolescents from urban areas; and, lest one is tempted to romanticize the whole rural world as a place for adolescents, see also Matthews and Tucker, 2006).

Psychology, as a whole, has much less awareness of cultural differences than has anthropology: textbooks of psychology tend to make their statements as if we all lived in the same material and psychological worlds. Yet, as a simple study of everyday life in a Malaysian kampong (Latif and Spencer, 1981) showed, the local awareness of natural and celestial rhythms is so much greater in such rural settlements than in urban settings that time reckoning and indeed the very psychological structuring of the day is importantly affected. Contrast this with the urban settings described by Faber Taylor, Kuo and Sullivan (2002).

We need researchers who are conversant both with the concepts of $E B$, and with the cultural sensitivity of the anthropologist: an example would be Wang's (2008) study of the sense of place and social structure in the Chinese courtyard residence.

And, if I may end on a personal note, the launch of the ajE-Bs is exciting for me, for it was South East Asia that made me into an environmental psychologist, making me aware of the importance of the physical environment in explaining behaviour. I had been a conventional social psychologist, a discipline for which 'environment' only signified the social environment in which the individual operated. I came to Malaysia to teach psychology, and had the opportunity to participate in some primatology field studies. During these, we were following populations of the same species of long-tailed macaque in deep jungle at Krau, and in an urban-fringe park in Penang; and we observed striking differences between the settings in both the behaviour and in the groups' social structure. Now, no biologist would fail to give these contrasting ecologies due weight in their account, so I wondered why did psychologists so conspicuously ignore the physical environment in theirs? I was converted to the cause, and shortly afterwards helped found the Journal of Environmental Psychology, which, together with Environment and Behavior [sic) has gone on to fly the flag for EB studies. 


\section{References}

Blades, M, Blaut, J., Darvizeh, Z., Elguea, S. , Soni, D., Sowden, S., Stea, D., Surajpaul, R.,and Uttal, D. (1998). A Cross-Cultural Study of Young Children's Mapping Abilities, Transactions of the Institute of British Geographers, Vol. 23, (1998), 269-277.

Blaut, J., Stea, D., Spencer, C., and Blades, (2003), M., Mapping as a Cultural and Cognitive Universal, Annals of the Association of American Geographers, 2003, 93, 165-185

Chawla, L. (Ed.) (2002). Growing Up in an Urbanising World. Paris / London: UNESCO Publishing / Earthscan..

Clark, C. \& Uzzell D. L. (2006). The socio-environmental affordances of adolescents' environments. In: Spencer, C. \& Blades, M. (Eds.), Children and their environments. Learning, using and designing spaces (pp 176195). Cambridge: Cambridge University Press.

Cornell, E H and Hill, K A (2006), The problem of lost children, In C. Spencer \& M. Blades (Eds.), Children and their environments. Leaming, using and designing spaces (pp.26-41). Cambridge: Cambridge University Press

Evans, G.W. (2006), Child development and the physical environment. Annual Review orPsychology, 57, 423-451.

Faber Taylor A, Kuo, EE., \& Sullivan, W.C. (2002). Views of nature and self-discipline: evidence from inner city children. Joumal of Environmental Psychology, 22, 49-63.

Kaplan, S. (1995). The restorative effects of nature: toward an integrative framework. Joumal of Environmental Psychology, 15,169-182.

Korpela K., Kytt.l. M. \& Hartig T. (2002). Restorative experience, self-regulation, and children's place preferences. Journal of Environmental Psychology, 22, 387-398.

Latif, R. and Spencer, C.P. (1981)'The time in Bukit Perah: Time reckoning in a kampong in Kelantan, Malay sia', Eastem Anthropologist., 34 (1981), 207212.

Lawson, B. R., \& Spencer, C. P. (1978). Architectural intentions and user responses: the psychology building at Sheffield. The Architects' Journal, 167(18).

Lawson, B.R. (2002) Healing Architecture, The Architectural Review, vol CCXI, no 1261 pp 72-75

Lynch, K. (ed). (1977). Growing Up in Cities. London: The MIT Press and UNESCO.

Matthews, H \& Tucker, E (2006). On the other side of the tracks: the psychogeographies and everyday lives of rural teenagers in the UK. In C. Spencer \& M. Blades (Eds.), Children and their environments. Leaming, using and designing spaces (pp.161-175). Cambridge: Cambridge University Press.

Wang, D. (2008). A form of affection: sense of place and social structure in the Chinese courtyard residence. Journal of Interior Design, 32, 28 - 39. 